\title{
Los Composites y la Construcción: Su ayer, hoy y mañana
}

\section{Composites and Construction: Yesterday, today and tomorrow}

Fecha de recepción: 7-III-97

Fecha de aceptación: 6-V-97
JUAN MANSO, Asesor Técnico de COMPOSTEEL TECHNOLOGIES, S.I

MADRID/ESPAÑA

\section{RESUMEN}

Vamos a tratar de dar una idea de las posibilidades que los Materiales Compuestos tienen en la Construcción, examinando, a lo largo del tiempo, diferentes aplicaciones.

Comenzamos por el cerramiento lateral de edificios, basado, fundamentalmente, en el concepto del panel sandwich.

Seguidamente comentaremos un nuevo material, llamado COMPOSTEEL, hibrido de composites y acero y orientado al mundo estructural.

Continuaremos con un nuevo diseño, el "Marco Continuo" también enfocado al campo estructural.

Finalmente, terminaremos con dos ideas que pueden convertirse en realidad:

a) Composites como solución de los fenómenos sismicos.

b) Composites en el cerramiento de grandes luces.

\section{SUMMARY}

We will try to give a idea about the possibilities of the Composites Materials in the Construccion area, examining their applications since along time.

We will begin by the integral closing the building, based in the panel sandwich concept.

Immediately we will comment a new material, the COMPOSTEEL, a hybrid product made of composites plus steel, indicated to the structural country.

Next, we will study the "Continuous Frame" oriented also at the structural area.

Finally, we will finish with two ideas:

a) The composites solving the seism phenomenon.

b) The composites as a ceiling to big areas.

\section{INTRODUCCIÓN}

Si bien los COMPOSITES de matriz polimérica y fibras de refuerzo, esencialmente vidrio, son relativamente materiales jóvenes, pues no sobrepasan los cincuenta años, ya han dejado constancia de sus notables peculiaridades, a través de innumerables obras civiles, repartidas, sobre todo, en el mundo occidental.

\section{INTRODUCTION}

Although Composites of polymeric matrix and fibers for reinforcement, glass essentially, are relatively young materials (no more than 50 years), they had already shown their great peculiarities through countless civil works distributed all over the occidental world. 
Los Composites han de ser, lo son ya, aunque modestamente, la respuesta a innumerables problemas que plantea el siglo XXI.

Los Composites resolvieron los problemas planteados con la triple E: Elegancia, Eficiencia, Economía.

Cerraremos esta exposición con un comentario hacia dos nuevos campos de aplicación:

a) Los Composites como respuesta a los problemas sísmicos.

b) Los Composites como cerramiento de grandes luces.

Pensamos que en ambos temas, los Composites tienen mucho que decir.

\section{POLÍMEROS REFORZADOS CON FIBRA (PRF)}

Son conocidas desde hace tiempo las notables ventajas que aportan los Composites, pero en particular y en el sector de la construcción, éstas se hacen aún más patentes.

Primeramente, su ligereza; pesan menos que el hormigón, el acero o el aluminio. Estos nuevos materiales (para simplificar los llamaremos, de ahora en adelante, PRF o Polímeros Reforzados con Fibra) constituyen uno de los materiales más resistentes que existen actualmente en el mercado. Consecuencia de su gran resistencia mecánica, admiten espesores muy pequeños, lo que facilita su empleo y, sobre todo, la amplitud de su diseño, con repercusión en la modularidad y en la dimensionalidad.

Los PRF, consituidos por una combinacion adecuada de una matriz (resina) y de un refuerzo (generalmente, fibra de vidrio), admiten sin problemas la curvatura, ondulación y nervadura. Pero hay más; es con los PRF donde el concepto sandwich adquiere toda su razón de ser, pudiendo, a voluntad, según nos dicta el cálculo, variar el espesor del alma. De esta manera, se responde óptimamente a la solicitud de rígidez necesaria en cada punto.

Citemos aun su gran resistencia a numerosos productos químicos, intemperie, corrosión, resistencia al choque, aislamiento eléctrico y durabilidad.

A estas características, propiamente inherentes al producto en sí, hay que sumar las de diseño, con una ilimitada capacidad de formas y colores, incluso en masa.

Otro factor muy a tener en cuenta es la Integración, es decir, la capacidad que tienen, basada en la aptitud al
Composites are and have to be the answer to countless problems that the next century presents.

Composites solved the problems stated by triple E: Elegance, Efficiency, Economy.

We will close this exposition with a comment in two new areas of application,

a) The Composites as an answer for sismic problems

b) The Composites as ceiling big speaces

We think Composites have too many things to say in both areas.

\section{POLIMERS REINFORCED WITH FIBER (PRF)}

The advantages provided by Composites are known since long time ago, but they are clearer in the construction section.

Firstly, its lightness; they weight less than concrete, steel or aluminium. These new materials (from now on PRF or Polymers Reinforced with Fiber) constitute one of the most resisting materials of the market nowadays. As a consequence of its big mechanical resistance they admit very little thicknesses that makes much easier its use and more extensive its design, influencing the modularity and the dimensionallity.

$P R F$, made of an adecuate combination of a matrix (resin) and a reinforcement (fiber glass generally), admit without problems the curvature, corrugated and nervure. Furthermore with PRF the sandwich concept acquires its sense, being possible, as the calculation indicates, change the soul's thickness. In this way, the solicitude of rigidity necessary in each point is answered positively.

Also we can add its strong resistance to a lot of chemical products, outdoors, corrosion, resistance to impact, electric and thermal insulation.

Even the design presents attractive characteristics, with an unlimited capacity of shapes and colours, even in mass.

Another important factor is the Integration, the capacity they have, based on the aptitude for design, to 
diseño, de sustituir varias piezas en una sola, con la economía en cascada que esto conlleva (gestión de almacén, gestión de pedido, manipulación, montaje, entre otros).

No olvidemos la resistencia al fuego, mediante la eleccion apropiada de resinas y aditivos, facilidad de mantenimiento y costo de utillaje moderado. Como notoriedad, según requiramos o no, los PRF pueden suministrarse opacos o translúcidos, con la economía que ello representaría en energía eléctrica y el descanso visual que supone para nuestro ojo, puesto que nos llegaría luz difusa y nunca luz puntual.

Referente a temas concretos como son las fijaciones, se han desarrollado sistemas de fijación que permiten resolver el problema de la expansión térmica diferencial ante las estructuras portantes y los paneles de revestimiento. Los paneles en composites forman parte integrante de la estructura del inmueble, transmitiendo y soportando esfuerzos notables, como seguidamente veremos. No son meros paneles de revestimiento. Enumeraremos algunas de estas aplicaciones:

Perfiles, paneles, paramentos, techados, muros cortina, marcos de ventanas, cúpulas, encofrados, domos espaciales, cubiertas en lámina delgada y paneles sandwich.

La utilizacion de los PRF, se encontrará tanto en aplicaciones sencillas como en las sofisticadas, tanto en simples obras estéticas y decorativas como en la renovación de viejos inmuebles o en el desarrollo de aplicaciones estructurales.

\section{CONCEPTO SANDWICH}

El alma está constituida por un material ligero y poco rígido, como la madera de balsa, espuma de PVC, de poliuretano, fenólica, el contraplacado o incluso panel aislante de lana de vidrio. El alma se recubre por un fino revestimiento en compuesto/resistencia cortadura), evitándose, así, los problemas de pandeo. Nuevamente, un fino revestimiento en compuesto, nos da la necesaria resistencia y rigidez. Un panel sandwich presenta dos características muy apreciadas en el sector de la construcción: El factor aislamiento y las repercusiones economicas derivadas del movimiento y fijacion de materiales ligeros.

Las formas y colores de los acabados superficiales son ilimitadas, lo cual es muy importante en el medio ambiente.

Normalmente, el edificio dispone en los forjados de unos pies soldados a la estructura, que actúan como asientos. Los paneles, a su vez, disponen de unos replace some pieces by only one, with the economy that it brings (store managing, orders managing, handling, assemblings among others)

We can't forget the resistance to the fire through the proper election of resins and additives, facility of maintenance and moderate tool cost. PRF can be provided opaque or translucent, with the economy that it would represent in electric energy and the visual rest for our eyes because the light would arrive always diffuse and never punctual.

With respect to other subjects like fixations, fixing systems have been developed and they allow to solve the problem between the thermal expansion and the structures and the revetment panels. The Composites become an integral part of building structure, transmitting and supporting great stresses. Following are some of the applications.

Profiles, panels, hanging, roofs, walls, window frames, domes, timberings, shelter deck and sandwich panels.

PRF will be used in simple and sophisticated applications, in aesthetic and decorative works, in old building renovation or structural applications development.

\section{SANDWICH CONCEPT}

The core is constituted by a light material of low rigidity, such as balsa wood; PVC foam, polyuretane, phenolic, plywood or insulationg wool. The core is covered by the very thin composite skin, that takes the Shear Stress, avoiding the bending problem. Again, very thin skin composite material give us the necessary strength and stiffness. The sandwich panel has two very appreciated characteristics in the construcction sector: the insulation factor and, more important, the financial repercussion at the moving and the fitting lighter.

The shapes and colours of the finished surface is completetly unlimited, which is very important in the ecological areas.

A building usually disposes in the forged a feet billet, like a bed. The panels also dispose the contre feet billet. The fitting and adjuntment may do it with the air 
contrapies, recibidos en el momento de la fabricación. Pies y contapies se ensamblan, realizándose el ajuste por medio de nivel y plomada. Todos los paneles dilatarán y contraerán a un mismo tiempo y en una sola dirección, porque van fijos y colgados de arriba, pero libres y con perforación en coliso abajo. Esta fue la gran aportacion de España hace 5 lustros y que ha sido seguida, a raíz de entonces, por todo el gremio. (1)

Las juntas se resuelven perfectamente por medio de adhesivo de silicona autovulcanizable en frio, capaz de absorber movimientos de más del $300 \%$. La unidad, sellado, estanquidad y funcionalidad de la fachada, queda asegurada.

\section{ESTRUCTURAS}

Hoy en día, al abordar las aplicaciones estructurales en arquitectura, a menudo nos llevan a considerar los compuestos fabricados por el proceso de pultrusión. El proceso de pultrusion permite obtener perfiles y piezas de sección continua, totalmente terminados y en continuo, en teoría, longitud indefinida y en donde las fibras de refuerzo se orientan y posicionan dónde, cómo y en la cantidad que a uno convenga.

Uno de los criterios resistentes, sin duda el más utilizado por los técnicos, es el de diseño a rigidez y es bien conocido que puede alcanzarse por el producto de dos factores:

a) la rigidez propia del material ("E", o Módulo de Young) de cada material.

b) el Momento de Inercia o "I", en donde interviene la geometría, sección o configuración del material. Si la "E" es baja, habremos de actuar sobre la "I" y viceversa. Naturalmente y para no sobrepasar una sección o geometría dada, que afectaría al peso o la cantidad de material interviniente, es decir, su precio $/ \mathrm{kg}$, tenderemos, a utilizar materiales con altos valores de "E" o Módulos de Young.

Un típico Módulo de Young en un material compuesto sería, con respecto al acero, de 6 a 10 veces menor, en función del tipo y de la proporción, en peso, de fibra.

En vista de ello, resolvimos trabajar simultáneamente con ambos materiales: el compuesto y el acero.

La idea fue unir ambos productos, el acero y el composite en un producto hibrido, producido de forma automatizada, y al que bautizamos con el nombre "COMPOSTEEL"(2). level and plumb level. The panels will shrink or expand at the same time and direction, because they are fixed at the top yet free at a slotted the bottom. This has been Spain's most notable contribution in the seventy yet it is still used to this day (1).

The joint are perfectly solved using silicon bonds capable to expanding $300 \%$ thereby providing an absolute unity of the building.

\section{STRUCTURES}

Today discussions regarding structural architectural applications often lead to talk of the intrinsic advantages of pultruded composites parts. Pultrusion process, furnishes the parts in a continuous section (theoretical of unlimited length), with the fibers oriented in the maximum length.

In the mechanical process, stiffness is one of the most important criterion. This may be accomplished in two different ways:

a) by the self material (E or Young's Modulus)

b) Inertial Moment, named "I" (fonction of the geometrical design). The product "I $x E$ " will account for the final rigidity. If " $E$ " is low, " $I$ " would have to be high, and vice versa. Obviously, an engineer will work towards the maximum " $E$ " because an increase in " $I$ " is equivalent to a higher section, a higher weight, and finally, higher cost.

The typical Young's Modulus is composite 6 at 10 times lower than steel (depending the type and the weight proportion's fiber in composite).

We are resolved to work simulatiously both materials: composite with the steel.

Having resolved this problem, the composite is then combined with steel in order to obtain a very successfull Hybrid material named "COMPOSTEEL"; produced automatically and in continuous process (2). 
El nuevo material COMPOSTEEL, nos proporcionará:

- Tres veces más rigidez que el mejor de los compuestos

- Un inmejorable precio

- Máxima consideración del acero

- Diseño y Color proporcionados por el compuesto

- Máxima automatización en el proceso productivo

Además, desarrollamos un concepto orientado a los procesos de Ingeniería. En nuestra opinion, la fabricacion de un convencional chasis o bastidor, crea y plantea problemas constructivos, no bien resueltos.

Permítanme, por un instante, examinar el caso de un chasis de camión. Hoy se produce esta estructura de forma similar a la de hace 70 años, utilizando una tecnología, consistente en dos perfiles de acero o largueros y una serie de piezas o travesaños, unidos a los anteriores por medio de insertos. Es una técnica similar a la que utilizamos en los marcos de ventanas, puertas, plataformas, etc.

La tecnología, basada en crear cuadrantes entre los largueros y travesaños, uniéndolos entre sí por soldadura, tornillos o remaches, lleva a costos elevados.

Existe, evidentemente, una estrecha relación entre un material y su proceso de manufacturación.

\section{CARACTERÍSTICAS DE LAS PIEZAS FABRICADAS}

Los materiales compuestos resuelven este problema basándose en una sección abierta, en forma de " $U$ ".

Con esta "U" podemos fabricar una configuración rectangular, circular, elíptica o contranegativa, pero siempre en forma continua y con las alas de la " $U$ " mirando hacia adentro.

Esta continuidad permite evitar las roturas a $90^{\circ}$ ó $45^{\circ}$ como ocurre en las estructuras metálicas, eliminando juntas, soldaduras, tornillos o cartelas de refuerzo. Esto significa romper con el tradicional concepto de ingeniería.

El resultado de esta tecnología, aparte de su limpieza y belleza, supondrá que nunca romperá por los ángulos, porque, simplemente, es dos veces más resistente.

En otras palabras, ha cambiado el orden de resistencia y los puntos considerados más débiles (ángulos) han pasado a ser los más resistentes.

Es posible cerrar los tramos rectos y abiertos de seccion en "U", con un perfil en "U" ó contra "U", logrando una perfecta viga cajón.
The new material, COMPOSTEEL, gives us:

- Three times more stiffness than even the best composites

- Better priced

- Highly respectfullness of steel

- Color and design as in rypical composites

- Maximum automatisation in the production process

We have nevertheless developed another solution oriented to the engineering process. The technical and more economical solution to a structure type frame or chassis, has created a real constructive problem that, in our opinion hasn't been solved in a convincing way.

Let us take, for instance, the case of a truck's frame. This structural part is produced today in the same way produced 70 years ago, by using a technology consisting of two steel profiles and a series of cross-pieced joined to the previous profiles on the basis of metallic parts with their corresponding bolts. It's the same technique used to produce window frames and door frames, loading platform, etc.

The technology consisting in manufacturing straight metallic profiles, joined together by means of quadrants, weldings or bolts, is the basis of its difficulty and high consequent cost.

The close relation between a specific material and its manufacturing process comes to light once again.

\section{CHARACTERISTICS OF MANUFACTURED PARTS}

Let us say first that the part we have taken into consideration is " $U$ " shaped and therefore open.

The profile may be rectangular, circular, elliptic or pear shape, but always in a continuous way and with the profile wings facing each other.

This continuity of the structure avoids break at $90^{\circ}$ or $45^{\circ}$ as it has been the case with metallic structures, by remowing joints solderings, bolts or reinforcement parts. This means breaking with the traditional engineer concept of today.

The result of this technology apart from its cleaner and more precise line is that the structure will never break at the angles, simply because it is twice as resistant at those points:

In other words, the order of resistance has changed places and the point that was presiously considered weak (the corner) is now the more resistant point.

It is possible to close the straight and open section, with a " $U$ "shaped intersection in composite intersection, obtaining a perfect box girder. 
Esto evitaría el que las alas abiertas se deformaran, eliminando el par torsor sobre el perfil. Esto, evidentemente, nos lleva a un amplio abanico de posibilidades cuando utilizamos los materiales compuestos en el campo estructural (3).

\section{LOS MATERIALES COMPUESTOS FRENTE A LOS FENÓMENOS SÍSMICOS}

Con demasiada frecuencia leemos cómo la tierra tiembla y causa pérdidas humanas y cuantiosos daños en numerosos países del mundo.

Las más de las veces, estos fenómenos se dan en países de bajo nivel de desarrollo y con población muy diseminada, que no tiene recursos económicos ni tecnología adecuada para hacer frente a este gran azote que, periódicamente, sacude nuestra tierra. No es lo mismo un temblor de tierra en San Francisco o Tokyo, por ejemplo, que en Irán, Argelia o Turquía. ¿Podría hacerse algo para resolver esta cuestión?

\section{CONCEPTO DE SEÍSMO}

Antes que nada, habría que interpretar bien el concepto del seísmo en sí. Si admitimos que en un terremoto se libera una alta cantidad de energía, emitida en forma vibratoria, ésta deberá ser absorbida, en un tiempo muy corto, por los diversos materiales que la onda encuentra a su paso. $\mathrm{Y}$ aquí viene el problema. La inmensa mayoría de los materiales utilizados en las construcciones de los países de menor nivel de desarrollo, presentan, a nuestro modo de ver:

1. Muy bajo nivel de cohesión

2. Demasiada rigidez

3. Un diseño en construcciones que no es el más adecuado

Cada uno de estos tres importantes factores ya son, de por sí, suficiente causa para provocar el desastre. Desgraciadamente, en la mayoria de las veces, se dan los tres a la vez.

La reacción del mundo ante estos hechos consumados, es siempre la misma: ayuda humanitaria que alivie el dolor de los que han sobrevivido. Nuestra sugerencia va más allá. Se trata de evitar estas secuelas, por medio del uso de los composites y empleando diseños más acordes con el problema (4).

\section{APTITUD DE LOS COMPOSITES}

Examinaremos, brevemente, los tres puntos anteriormente citados.
This would avoid the possibility of the wings opening and strengthening the structure at the same time; eliminating the torque working over the profile. This evidently leads to a wide scope of possibilities which are unthinkeable when using Composites in the structural field. (3)

\section{THE COMPOSITES VERSUS THE SEISM PHENOMENON}

Too often, it seams, we are reminded of the disaster caused by earthquakes.

Along with thousands of deaths and injuries there is economic damage and often the seisms take place in countries with low economic activity, which are unable to develop new and safer materials or techologies. Most of these countries, however, have yet another problem: the broad population. Living conditions in Tokyo or San Francisco are not comparable to Algeria, Turkey or Iran. Is it possible to solve this issue?

\section{SEISM CONCEPT}

We believe it is important to understand the seism phenomenon first. An earthquake set at liberty emits a very high level of vibrating energy in a very short period of time. The different materials which receive these high levels of energy should be able to absorb them. Following are the most common properties associated with conventional materials:

\section{Very low levels of cohesion force \\ 2. Excessive rigididy \\ 3. Improper and unsuitable architectural designs}

Each of the three may cause a given disaster individually. Unfortunately, the three may also work jointly.

The world reaction is always the same: to send help and assistance to the survivers. Nothing to the dead people, though. What can we do to avoid this problem in the future? (4).

\section{THE COMPOSITE'S SUITABILITY}

We shall explain briefly the last three characteristics. 
- La matriz de los composites está constituida por una resina polimérica, formada por un esqueleto de átomos de carbono, unidos por enlaces covalentes, es decir, electrones de enlace compartidos, 0 , lo que es lo mismo, quedan sólidamente unidos los carbonos entre sí. Esta fuerza de unión es muy superior a la que presentan las uniones en base a los revestimientos y argamasas utilizadas en las construcciones (ej. morteros de cemento, ladrillo, arcilla, arena). Si además, el polímero viene reforzado por fibras de vidrio distribuidas en toda la masa, con una plena integración y unión, basada tanto en aspectos físicos como químicos, dispondremos de materiales con resistencias a la tracción entre $12.000 \mathrm{~kg} / \mathrm{cm}^{2}$ y $1.250 \mathrm{~kg} / \mathrm{cm}^{2}$, en función del tipo y cuantía de fibra de vidrio escogido. Si lo que se utilizan son adobes (quizás el primer composite de la historia, formado por barro y paja) o ladrillos, en los que en la unión entre sí vuelve a responsabilizarse al mortero de cemento, el problema continuará.

- Los lienzos o paramentos de cierre laterales, techos y forjados, de por sí constituidos por elementos rigidos, se apoyan en vigas y pilares, también rigidos. Cuando unos y otros reciben las ondas vibratorias, no las absorben suficientemente, sobreviniendo la disgregación de muros, techos y forjados de los soportes que los mantienen, sobreviniendo el derrumbe.

El Módulo de Young de los composites en fibra de vidrio es entre 3 y 10 veces (en función, nuevamente, del tipo y cuantía del refuerzo) inferior al hormigón armado, por ejemplo. Es decir, falta elasticidad y sobra rigidez.

- Son necesarios nuevos diseños constructivos en las zonas sísmicas. Siguen utilizándose los encuentros de líneas horizontales (vigas, cerchas) con verticales (pilares), por tanto, tendremos siempre concentración de esfuerzos en los puntos de unión, puntos críticos. Entre el tramo vertical y el horizontal, debe existir una continuidad, que transmita, no ángulos rectos que rompen. Este es el diseño propio de los composites con el ya apuntado desarrollo del "Marco Continuo".

Pueden diseñarse marcos continuos, a modo de cuadernas, que recibirían paneles de forjados, techos y laterales, bien de pieles simples, de unos pocos milímetros de espesor o sandwich, máxima expresión de la máxima rigidez, con relación al peso.

\section{CARACTERÍSTICAS DE LOS COMPOSITES}

A nivel de componente de partida, esto son algunos de los rasgos que ofrecen los composites:
- Composites are new materials made of reinforced fiber and a type of polymeric matrix naimed resin. Both fiber and resin share several relevant properties that contribute to our solution. At the skeleton of the resin structure, we find carbon atoms well known for their high bond energy. This electronic bond energy is higher than in those products based in water (i.e. cement mortar, brick, clay, slag). If, in addition, the polymer is reinforced with glass fibres distributed through the whole mass, with a full integration and cohesion based on physical as much as on chemical aspects, we will get materials with a tensile strengh of $12.000 \mathrm{~kg} / \mathrm{cm}^{2}$ and $1.250 \mathrm{~kg} / \mathrm{cm}^{2}$ depending on the type and quantity of the chosen fibre.

If unbaked brick is used (perhaps the first composite in history, made of clay and straw) or bricks whose cohesion between them is again the resposibility of the cement mortar, the problem will keep going on.

- If the roof or the building's sides are made of either concrete, brick or stone, which are too rigid, in a sismic move they will fall because the materials can not successfully absorb the deformations. It becomes inevitable.

Composite products, though based in fiber glass, because the Young's Modulus is 3 to 10 times inferior to steel, can be included among the elastic group materials. The very interesting sandwich concept can further be used to solve the stiffness to weight dilemma.

- It seems that we need a new design based on new materials. Among the vertical and horizontal structure lines, for instance, it would be wise to include a mechanical transmitter, rather than a square elbow, in order to provide the desired continuity. It's our concept named "Continuous Frame": the ideal solution to apply in the sismic areas.

With the continual frame technology, one could manufacture tables, gangways, signposting panels, electrical towers, ceilings of industrial buildings, dwellings and lots of applications where the third dimension get close to the requirements of weight, rigidity, electrical and thermal isolation.

\section{COMPOSITE'S CHARACTERISTICS}

Following is a list of the basic properties that composites can provide: 
- Mejor elección de tipos de fibra de refuerzo

- Mejor porcentaje de fibras de refuerzo

- Mejor orientación a discreción de la fibra de refuerzo

- Mejor elección del tipo de matriz más adecuado

- Mejor color y terminación

- Ligereza (densidad $1,7 \mathrm{~kg} / \mathrm{dm}^{3}$ con fibra de vidrio) frente a 2,6 del cemento, 2,8 del aluminio y 7,8 del acero

- Diseño, como ningún otro material.

- Integración de formas, con simplificación y abaratamiento del montaje

- Opacidad o translucidez

- No corrosión y resistencia elevada a intemperie

- Aislamiento eléctrico, lo que da seguridad

- Aislamiento térmico (200 veces inferior al acero y 800 veces inferior al aluminio)

- Aceptación de elementos metálicos si fuera necesario (sistema COMPOSTEEL)

- Fácil reparación en caso de necesidad

- Fácil prefabricación y ensamblaje

\section{LOS COMPOSITES EN EL CERRAMIENTO DE GRANDES LUCES}

Consideramos interesante mencionar algunas de las aplicaciones de los Composites, como pueden ser los cerramientose de grandes espacios: campos de fútbol, polideportivos, pestas de tenis, piscinas, plazas de toros, iglesias, mercados, etc (5).

Incluimos diferentes figuras de una cúpula, una bóveda, una cubierta en forma de ala de avión y un voladizo con sistema catenario, de opciones múltiples, muy sugestivo y apropiado para el uso de los materiales COMPOSITE (solos o combinados con materiales convencionales (Figuras 1 a 5).
- The best appropriate reinforced fiber

- The best weight percentage

- The best orientation as a function of stress

- The best resin in every application

- The best colour or appearance

-Very low composite density: $1.7 \mathrm{~kg} / \mathrm{dm}^{3}$ balanced to the steel $\left(7.8 \mathrm{~kg} / \mathrm{dm}^{3}\right)$ or aluminium $\left(2.8 \mathrm{~kg} / \mathrm{dm}^{3}\right)$, hence easy and affordable handling or transportation

- Easy to design freely

- Integration of shapes and materials

- Opaqueness or translucence

- Without corrosion (no metallic elements)

- Electrical Isolation (hence safety)

-Thermal Isolation (200 less to steel, 800 less to aluminium)

- If necessary, inclusion of steel rod or plate (COMPOSTEEL)

- Easy restoration in case of damage

- Easy prefabrication and assembly

\section{THE COMPOSITES IN THE BIG CEILING}

We find it interesting to include some possible applications of Composites in the roofing of bigger structures such as auditoriums: sports arenas, swimming pools, tennis courts, footbal stadiums, churches and shopping malls (5).

We include different figures of a dome, a barrel roof, a shell roof, an overhanging roof and a catenary system with multiple options, very suggestive and appropriate for the use of COMPOSITE materials (alone or combined with conventional materials) (Figures 1 to $5)$.

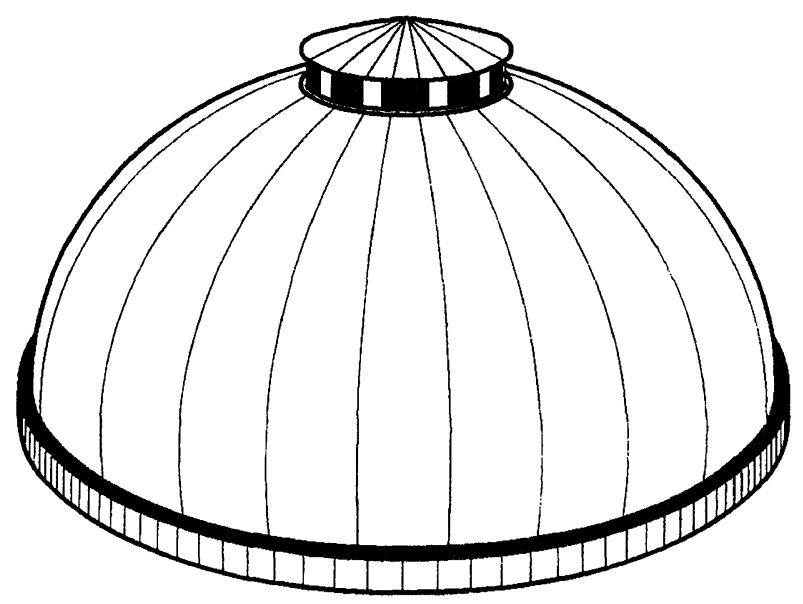

Fig 2.- Cúpula ventilada.

Fig. 2.- Draughty dome.
Fig. 1.- Cúpula móvil Fig. 1.- Mobile dome. 


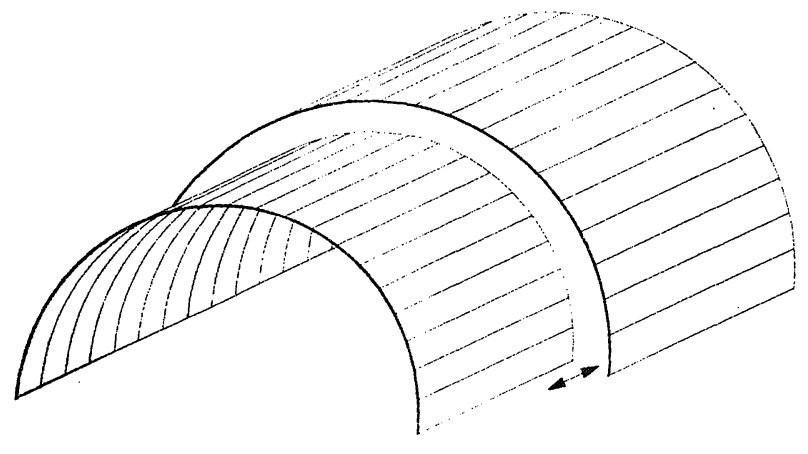

Fig. 3.- Bóveda de cañón.

Fig. 3.-Barrel roof.

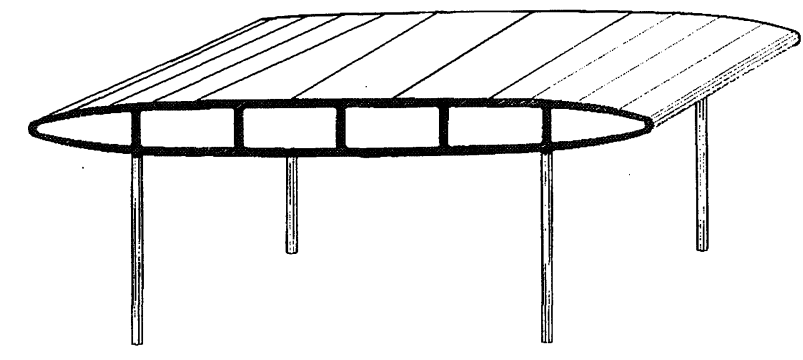

Fig 4.- Cubierta ala avión.

Fig. 4.- Wing cover.

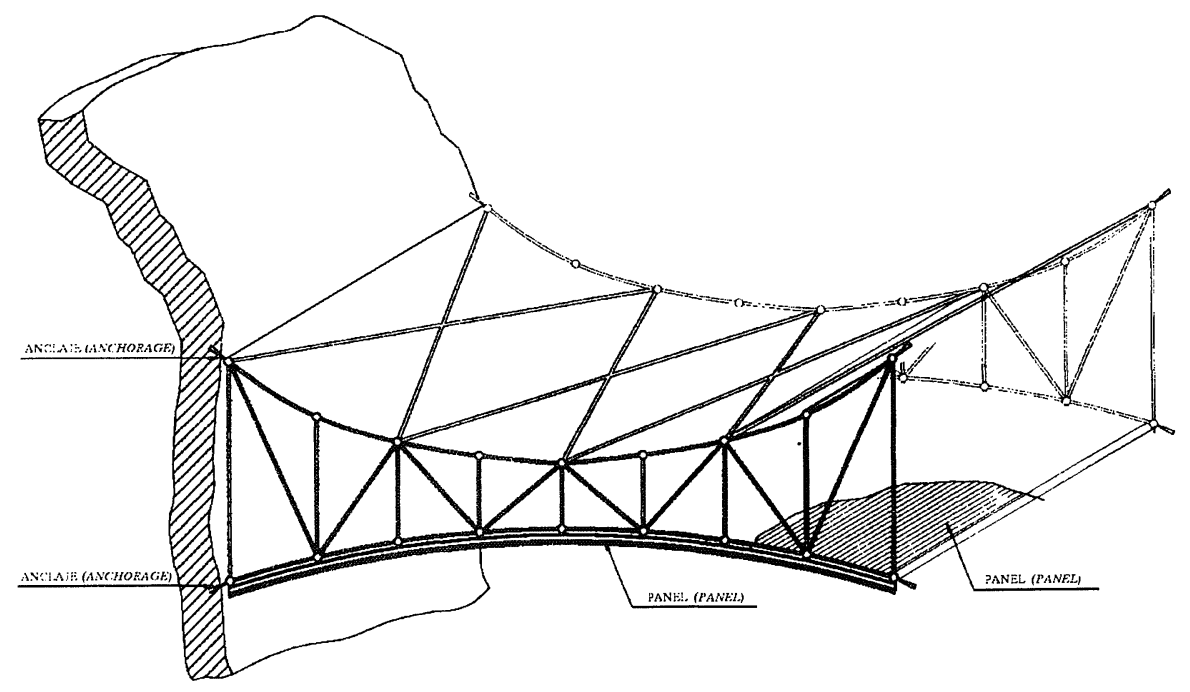

Fig. 5.- Techo suspendido.

Fig. 5.- Suspended ceiling.

\section{BIBLIOGRAFÍA}

(1) J. MANSO: IV Congreso de Materiales Compuestos. Barcelona, 1978.

(2) J. MANSO: XIII Congreso de Materiales Compuestos. Barcelona, 1996.

(3) J. MANSO: J.E.C. París, 1988.

(4) J. MANSO: Universidad Pontificia Bolivariana de Medellin, 1997.

(5) I Congreso AEMAC: Sevilla, 1995. 